\title{
HYPOXIA ENHANCES PROSTAGLANDIN SYNTHESIS IN RENAL MESANGIAL CELL CUL TURES
}

\author{
Wolfgang Jelkmann ${ }^{1,2}{ }_{2}$, Armin Kurtz ${ }^{2}$, Ulrigh Förstermann ${ }^{3}$, \\ Josef Pfeilschifter ${ }^{2}$ and Christian Bauer ${ }^{2}$ \\ ${ }^{2}$ Institut für Physiolggie der Universität, Universitätsstraße 31, \\ D-8400 Regensburg, and Pharmakologisches Institut der Universitä, \\ Hermann-Herder-Straße 5, D-7800 Freiburg, FRG
}

\section{ABSTRACT}

In view of recent findings which suggest that renal prostaglandins mediate the effect of hypoxia on erythropoietin production, we have studied whether hypoxia is a stimulus for in vitro prostaglandin synthesis. Studies were carried out in rat renal mesangial cell cultures which produce erythropoietin in an oxygen-dependent manner. Production rates of $\mathrm{PGE}_{2}$ and in specified samples also of 6-keto-PGF $l_{1}$, as a measure of PGI 2 , and PGF $2 \propto$ were determined by radioimmunoassay after incubation at either $20 \% 0_{2}$ (normoxic) or $2 \% \mathrm{O}_{2}$ (hypoxic) in gas permeable dishes for 24 hrs. Considerable variation in $\mathrm{PGE}_{2}$ production was noted among independent cell lines. $\mathrm{PGE}_{2}$ production appeared to be inversely correlated to the cellular density of the cultures. In addition, PGE production was enhanced in hypoxic cell cultures. The mean increase was 50 to $60 \%$. PGF 20 and 6-keto-PGF increased by about the same rate. These results indicate that hypoxia is a stimulus for in vitro prostaglandin production.

\section{INTRODUCTION}

Renal prostaglandins are thought to be involved in the mechanisms by which hypoxia induces the elaboration of erythropoietin. Prostaglandins of the E-type as well as prostacyclin ( $\mathrm{PGI}$ ) and its metabolite, 6-keto-PGE, enhance the production of erythropoietin in experimental animals (1) and in glomerular mesangial cell cultures (2). On the other hand, inhibitors of prostaglandin synthesis like indomethacin attenuate the hypoxia-induced production of erythropoietin in vivo $(1,3)$ and in vitro $(2,3)$. The constriction of the renal artery in dogs stimulates both erythropoietin and $\mathrm{PCE}_{2}$ release (4). We have recently shown that the elaboration of erythro-

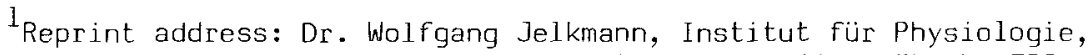
MHL, Ratzeburger Allee 160, D-2400 Lübeck, FRG 


\section{PROSTAGLANDINS}

poietin increases in mesangial cell cultures grown from rat glomeruli, when the oxygen concentration is lowered in the incubator $(5,6)$. It was the objective of the present study to investigate whether the synthesis of prostaglandins is also stimulated under these experimental conditions.

\section{METHODS}

Mesangial cell cultures

Glomeruli were isolated from mele Sprague-Dawley rats (70 - 100 9) by the sieving technique described in (5). About $60 \mathrm{glomeruli} / \mathrm{cm}^{2}$ were plated in $75 \mathrm{~cm}^{2}$ tissue flasks (Greiner, Nürtingen) with $15 \mathrm{ml}$ of medium. The medium consisted of RPMI 1640 with $10_{\%}^{\circ}$ fetal bovine serum (Boehringer, Mannheim), $100 \mathrm{IU} / \mathrm{ml}$ penicillin, $100 \mu \mathrm{g} / \mathrm{ml}$ streptomycin and $0.7 \mathrm{IU} / \mathrm{ml}$ insulin. Medium was changed every 2 - 3 days. Glomerular outgrowths were subcultured after 21 days in order to obtain homogeneous mesangial cell cultures (7). Usually $0.5-1.0 \times 10^{6}$ cells in $5 \mathrm{ml}$ medium were seeded per $25 \mathrm{~cm}^{2}$ culture dish. Dishes with a gas permeable bottom part were used (Petriperm®, Heraeus, Hanau). Incidentally, cells were also used for study after further passages. On day 7 of subculture and 24 hrs after the last medium change, the medium was carefully removed and substituted by fresh medium that had been pre-equilibrated in the incubator for 3 days, Cells were then incubated at $37^{\circ} \mathrm{C}$ in a humidified atmosphere containing $5 \% \mathrm{CO}_{2}$ and either $20 \%$ or $2 \% \mathrm{O}_{2} \quad \mathrm{O}_{2}$ and $\mathrm{CO}_{2}$ controlled incubators, Heraeus). 24 hrs later, samples of culture medium were taken and frozen in liquid nitrogen. They were then kept at $-60^{\circ} \mathrm{C}$ until assayed for prostaglandins and lactate.

In an additional experiment, the effect of cobalt chloride ( $10 \mu \mathrm{mol} / 1$ ) on $\mathrm{PGE}_{2}$ production was also assessed in culture. This experiment was carried out because cobalt is a potent stimulus for erythropoietin production in vivo (8) and in mesangial cell cultures (6).

\section{Assay of prostaglandins}

Prostaglandins in culture media were quantified by direct radioimmunoassays without prior extraction. Fresh incubation medium was used for blanks and binding controls.

$P G E_{2}$ was determined by a commercially available $\left({ }^{125} \mathrm{I}\right)$ radioimmunoassay kit (New England Nuclear, Dreieich, FRG).

Specific antibodies against 6 -keto-PGF $1 \alpha$ and PGF $2 \alpha$ were generated in rabbits as previously described $1 \%, 10)$. The radioimmunoassays węre performed as published $(9,10)$ using $5,8,9,11,12,14,15-$

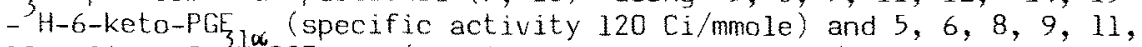
$12, \quad 14,15-$ H-PGF $\alpha$ (specific activity $150 \mathrm{ci} / \mathrm{mmole}$, both New England Nuclear, breieich, FRG) as the respective tracers. Free and 
antibody-bound fractions were separated using a charcoal suspension. The sensitivities of the assays (detection limit defined as $10 \%$ displacement of tracer) were $3 \mathrm{pg} / \mathrm{ml}$ for $\mathrm{PGE}_{2}, 16 \mathrm{pg} / \mathrm{ml}$ for 6-keto-PGF $1 \alpha$ and $10 \mathrm{pg} / \mathrm{ml}$ for $\mathrm{PGF}_{2 \infty}$.

Prostaglandin concentrations were related to the number of cells per dish and are expressed in $n g / 10^{6}$ cells. In order to disaggregate the cells, culture media were removed and $1 \mathrm{ml}$ of trypsin solution was added $(2.5 \mathrm{mg} / \mathrm{ml}$ trypsin - $0.18 \mathrm{mg} / \mathrm{ml}$ EDTA in Hank's balanred salt solution). Microscopic evaluation showed that the cells were completely disaggregated after $10 \mathrm{~min}$ of incubation. Aliquots were then taken from the cell suspensions and cell numbers determined in a Coulter Counter (Coulter Electronics, Krefeld).

\section{Assay of lactate}

Lactate production was determined as an index of cellular hypoxia. A commercial L-lactate assay kit was used (Boehringer, Mannheim). The values were corrected for lactate added with the culture media $(2 \mu \mathrm{mol} / \mathrm{ml})$.

\section{Statistical evaluation}

Data are expressed as the mean \pm standard error. Student's t-statistic was used to compare two group means for significance of difference. The Wilcoxon signed-ranks test was used to compare related groups. P was considered significant at the 0.05 level.

\section{RESUL TS}

Fig. I depicts PGE, production rates in eight independent mesangial cell Lines. PGE production was significantly greater in cultures maintained at $2 \% \mathrm{O}_{2}$ than at $20 \% \mathrm{O}_{2}$ (Wilcoxon test applied to compare cell line means). There was connsiderable variation in PGE production among the different cell lines. As reported below, prostaglandin synthesis depended on cell density. Therefore, it is noteworthy here that the numbers of cells per dish were not significantly different after incubation at $2 \% 0_{2}$ when compared to those of cultures from the same cell line after incubation at $20 \%$ $0_{2}$. The production of lactate was significantly greater in cultures mâintained at $2 \% 0_{z}\left(10.2 \pm 0.9 \mu \mathrm{mol} / 10^{6}\right.$ cells and $\left.24 \mathrm{hrs}, \Pi=25\right)$ than at $20 \% 0_{2}\left(6.5-0.3 \mu \mathrm{mol} / 10^{6}\right.$ cells and $\left.24 \mathrm{hrs}, \mathrm{n}=27\right)$.

Fig. 2 shows production rates of $\mathrm{PGE}_{2}, \mathrm{PGF}_{2} \alpha$ and 6-keto-PGF which were determined in three serial subcultures of the line, D. 'At $20 \% 0_{2}, 3.6 \mathrm{ng} P \mathrm{PE}_{2}, 2.5 \mathrm{ng} \mathrm{PGF}_{26_{6}}$ and $0.9 \mathrm{ng}$ 6-keto-PGF $1 \propto$ were produced $^{2}$ (mean values per $10^{6}$ cells and 24 hrs) ${ }^{1}$. At $2 \% 0_{2}$, prostaglandins formation increased significantly. Their percent 


\section{PROSTAGLANDINS}

increase was very similar: PGE $2:+56 \%, \mathrm{PGF}_{2} \alpha:+53 \%$ and 6 -keto-PGF $1 \alpha$ : $+41 \%$. Furthermore, prostaglandin $2 \alpha$ formation was enhanced when arachidonic acid $(10 \mu \mathrm{mol} / 1)$ was added to cells of the same line maintained at $20 \% \mathrm{O}_{2}$. Here, $8.3 \mathrm{ng}$ PGE, $5.1 \mathrm{ng}$ PGF $2 \%$ and $1.9 \mathrm{ng} 6$-keto-PGF $\alpha$ were prôduced per $10^{6}$ cells and 24 hrs thean of 2 determinations with closely similar results).

Cobalt chloride $(10 \mu m o l / 1)$ did not significantly stimulate the formation of $\mathrm{PGE}_{2}$ in this cell line $\left(3.8 \pm 0.8 \mathrm{ng} / 10^{\circ}\right.$ cells and 24 hrs; $n=7$ ).

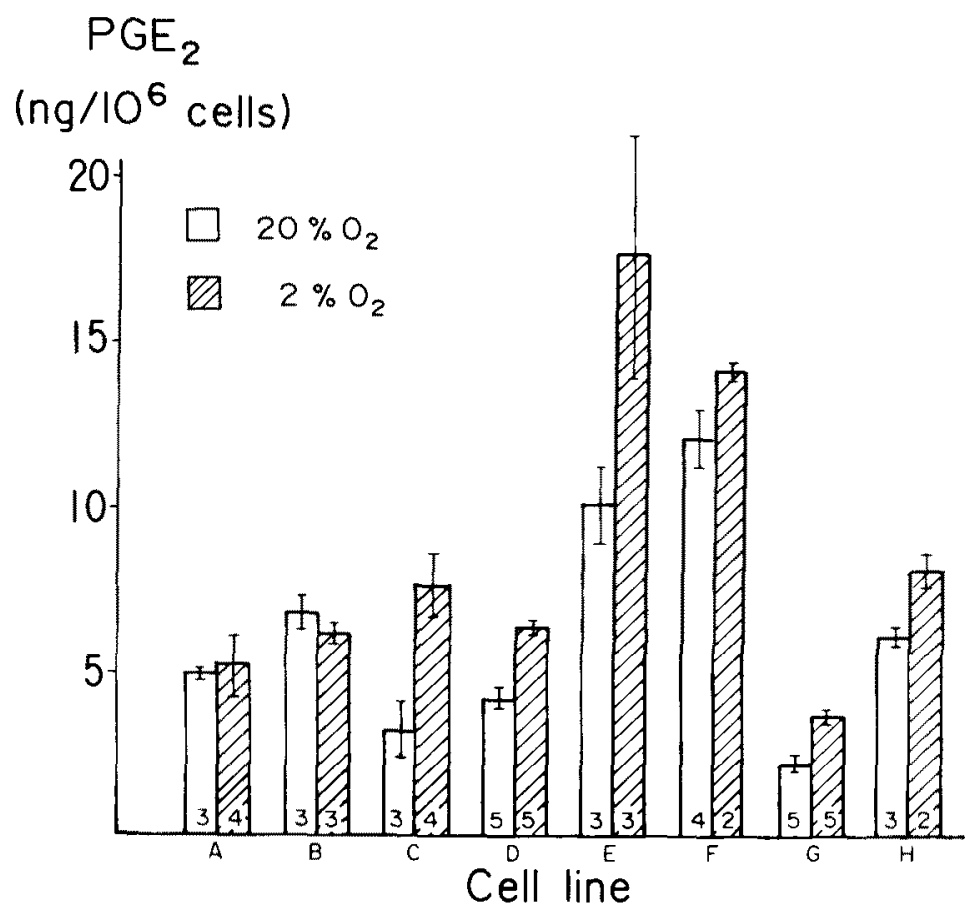

Fig. I PGE, production in 8 independent mesangial cell lines during 24 hrs of incubation at $20 \%$ or $2 \% 0 \%$. No. of measurements are given at the bottom of each bar. Hypoxic incubation caused a significant increase in the mean $\mathrm{PGE}_{2}$ production rate (Wilcoxon signed-ranks test).

Possibly, the relatively large scatter of PGE, formation among similarly treated cell lines (fig. I) resulted from differences in 
the cell density. Fig. 3 shows that the formation of PGE, tended to be lower in cultures with high cell density. The relationship between cell concentration and PGE formation per number of cells could have resulted from feedback inhibition of $\mathrm{PGE}_{2}$ synthesis. This possibility was further tested in experiments in which mesangial cells were incubated with $1 \mathrm{ml}$ instead of with $5 \mathrm{ml}$ medium. The results shown in Table 1 indicate that the formation of PGE ${ }_{2}$ per number of cells was indeed inhibited when the cell number to medium volume ratio was increased.

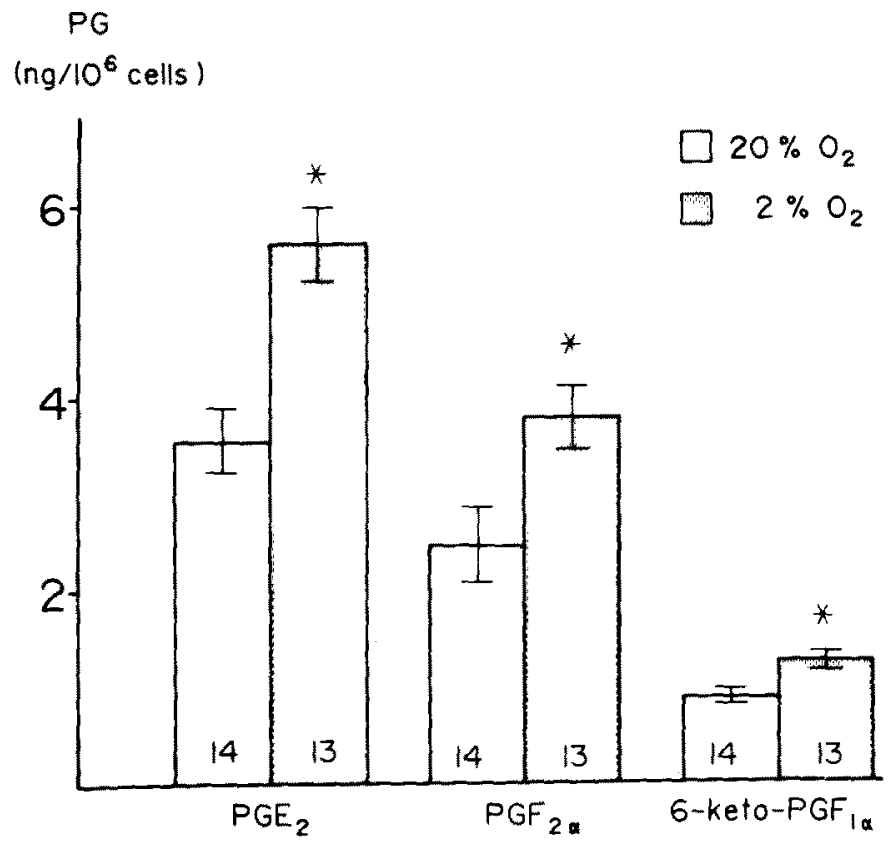

Fig. 2 Prostaglandin production in a mesangial cell culture (line 0 ) during 24 hrs of incubation at $20^{\circ}$ or $2 \% 0$ Asterisks indicate a significant increase at $P<0.65$ 'Student's $t$-test, No. of measurements are given at the bottom of each bar. 


\section{PROSTAGLANDINS}

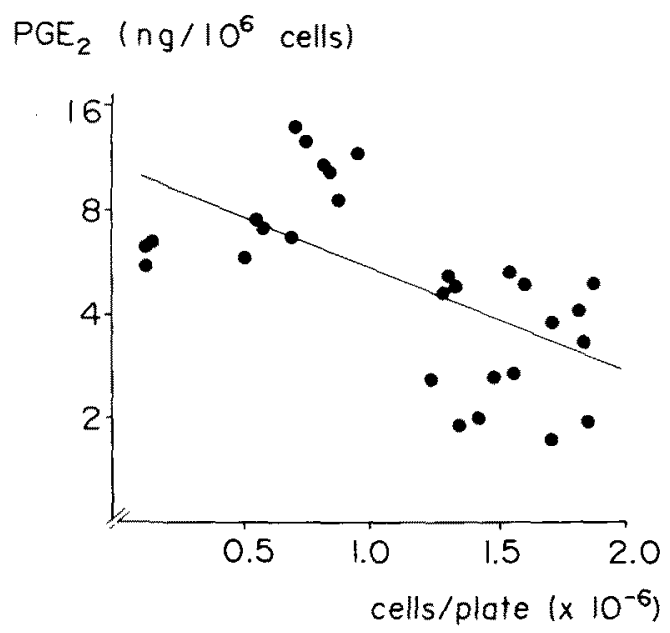

Fig. $3 \mathrm{PGE}_{2}$ production related to the cellular density in the culture dish ( $24 \mathrm{hrs}$ of incubation; $20 \% 0,0_{2}$ ). The correlation coefficient, $r$, is -0.63 in this semilogarithmic production.

Table 1. Influence of cell number to medium volume ratio on $\mathrm{PGE}_{2}$ formation $\left(20 \% \mathrm{O}_{2}\right)$.

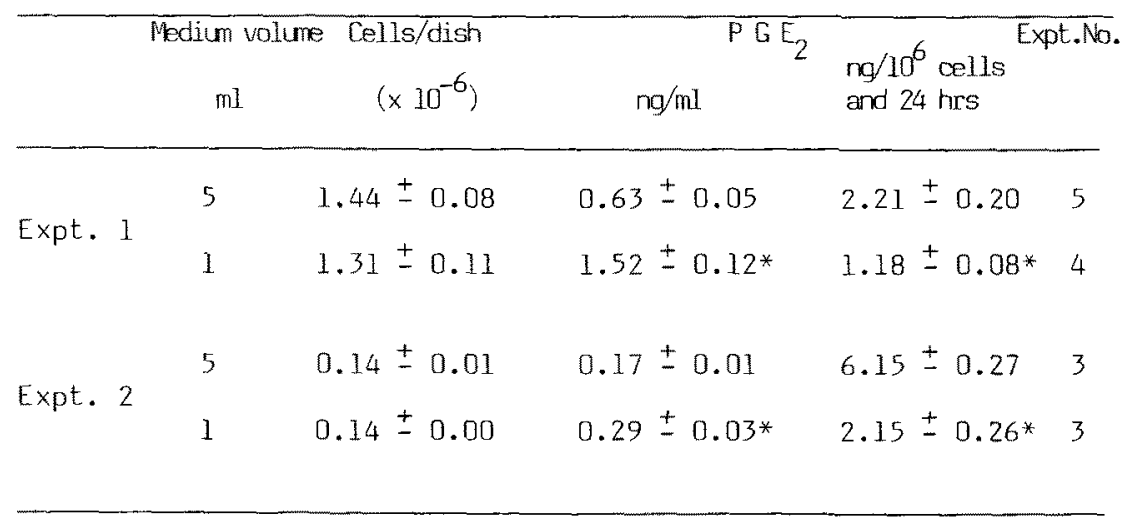

* significantly different from the respective $5 \mathrm{ml}$ value Mean \pm SEM 


\section{PROSTAGLANDINS}

\section{DISCUSSION}

Earlier studies have shown that isolated renal glomeruli ( 11 - 13) and cellular outgrowths from glomeruli produce $\mathrm{PGE}_{2}, \mathrm{PGF}_{2} \alpha$ and PGI $(13,14)$. A new finding in the present study was the increase in prostaglandin synthesis by glomerular mesangial cell cultures when the $\mathrm{O}_{2}$ concentration in the incubator was lowered from $20 \%$ to $2 \%$. Lactate production, as an index of cellular hypoxia, also increased during incubation at $2 \% 0$ demonstrated enhanced $\mathrm{PGE}_{2}$ formation by the intact kidney in dogs following renal artery constriction (4) or following the induction of hypoxemia (15). Isolated canine kidneys respond to hypoxemic perfusion with an increase in 6-keto-PGF $\alpha$ and thus probably PGI, production (16). Because PGI titers are also elevated in the perfusate of hypoxic hearts $(17,18), 0_{2}$ deficiency appears to be a common stimulus for prostaglandin production. Vasodilatatory prostaglandins produced in response to hypoxia may in turn improve the cellular $0_{2}$ supply (19).

Several hypotheses have been proposed to explain the mechanism by which hypoxia could affect prostaglandin synthesis (19). Our results show that PGE 2 , 6-keto-PGF $1 \propto$ and $\mathrm{PGF}_{2} \alpha$ increased by about the same rate during hypoxic incubation of mesangial cells. Thus hypoxia would not seem to interfere beyond the endoperoxide, $P G G_{2}$, level in the synthesis pathway of prostaglendins. It is more likely that the availability of free arachidonic acid increases under hypoxic conditions. Obviously the availability of arachidonic acid was limiting prostaglandin synthesis in our cultures, because elevated prostaglandin titers were found when exogenous arachidonic acid was added to the cells. There are several possibilities by which hypoxia could affect the pool of free arachidonic acid, including an activation of phospholipases because of an increase in the cytosalic Ca ${ }^{2+}$ concentration (19) or a decrease in the rate of fatty acid incorporation into glycerolipids because of a lowered ATP availability (20).

Both $\mathrm{PGE}_{2}$ and $\mathrm{PGI}$ stimulate the production of erythropoietin in mesangial ${ }^{2}$ cell cultures $(2,3)$. It remains to be proven whether the moderate increase of prostanoids production in hypoxic mesangial cell cultures is sufficient to stimulate the elaboration of erythropoietin. However, taken together with our previous observation that indomethacin inhibits the hypoxia-induced production of erythropoietin in mesangial cell cultures $(2,3)$, a link between the prostaglandin system and erythropoietin production appears likely. Hagiwara et al. (21) have recently demonstrated an important role of endogenous $\mathrm{PCE}_{2}$ in the mechanism of erythropoietin production by cultured renal carcinoma cells. As pointed out by these authors (21), the possibility still exists that the effect of prostanoids is unspecific, in that prostanoids are essential for renal cells to maintain their functions, including the production of erythropoietin. 


\section{PROSTAGLANDINS}

The effect of cobalt on erythropoietin production is apparently not mediated by prostaglandins. Cobalt did not stimulate the production of PGE, by mesangial cells. It has already been shown that cobalt does not affect $P G E$, synthesis in rabbit kidney medulla slices (22). In addition, the effect of cobalt on erythropoietin production in experimental animals is not attenuated by indomethacin (3).

The amount of $\mathrm{PGE}_{2}$ produced per culture dish increased with increasing mesangial celis density (Table 1). Hagiwara et al. (23) have already shown that erythropoietin production in human renal carcinoma cells in culture increases in parallel with increasing cell density. However, it was also observed in the present study that the rate of $\mathrm{PGE}_{2}$ production per number of cells was lowered when the culture medium to cell number ratio was increased. This result indicates a feedback inhibition of $\mathrm{PGE}_{2}$ synthesis. Declining PGE production at increasing cell density has already been demonstrated in porcine aortic smooth muscle and endothelial cell cultures (24). It is also reported in that study that the addition of fresh culture medium stimulated prostaglandin production, which leveled down, at the latest, after 24 hrs of culture (24). Thus in order to demonstrate more pronounced effects of stimuli of prostaglandin synthesis, experimental devices may be more suitable in which cultured cells are continuously perfused with fresh medium instead of being maintained in a small volume of resting medium.

\section{ACKNOWLEDGEMENTS}

This study was supported by the Deutsche Forschungsgemeinschaft (SFB 43-A 2).

The authors thank Mrs. Gisela Thaler for typing the manuscript.

\section{REFERENCES}

1) Fisher, J.W. Control of erythropoietin production. Proc. Soc. Exp. Biol. Med. 173:289, 1983.

2) Kurtz, A., Jelkmann, W., Pfeilschifter, J., and Bauer, C. Prostaglandins are involved in the hypoxia stimulated erythropoietin production in cultured renal mesangial cells. Am. J. Physiol. (in press).

3) Jelkmann, W., Kurtz, A., Seidl, J., and Bauer, C. In: Atemgaswechsel und $\mathrm{O}_{2}$-Versorgung der Organe. (3. Grote und E. Witzleb, eds.) Akademie der Wissenschaften und Literatur, Mainz, 1984. p. 130. 
4) Gross, D.M., Mujovic, V.M., Jubiz, W., and Fisher, J.W. Enhanced erythropoietin and prustaglandin $E$ production in the dog following renal artery constriction.

Proc. Soc. Exp. Biol. Med. 151:498, 1976.

5) Kurtz, A., Jelkmann, W., and Bauer, C. Mesangial cells derived from rat glomeruli produce an erythropoiesis stimulating factor in cell culture.

FEBS Lett. 137:129, 1982.

6) Kurtz, A., Jelkmann, W., Sinowatz, F., and Bauer, C. Renal mesangial cell cultures as a model for study of erythropoietin production. Proc. Nat1. Acad. Sci. USA 80:4008, 1983.

7) Foidart, J.B., Dechenne, C., Dubois, C., Deheneffe, J., and Mahieu, P. Tissue culture of isolated renal glomeruli: Present and future. Adv. Nephrol. 10:267, 1981.

8) Goldwasser, E., Jacobson, L.O., Fried, W., and Plzak, L.F. Studies on erythropoiesis. $V$. The effect of cobalt on the production of erythropoietin. Blood 13:55, 1958.

9) Peskar, B., and Hertting, G. Release of prostaglandins from isolated cat spleen by angiotensin and vasopressin. Naunyn-Schmiedeberg's Arch. Pharmacol. 279:227-234, 1973.

10) Machleidt, C., Förstermann, U., Anhut, H., and Hertting, G. Formation and elimination of prostacyclin metabolites in the cat in vivo as determined by radioimmunoassay of unextracted plasma. Eur. J. Pharmacol. 74:19-26, 1981.

11) Folkert, V.W. and Schlondorff, D. Prostaglandin synthesis in isolated glomeruli. Prostaglandins 17:79, 1979.

12) Hassid, A., Konieczkowski, M., and Dunn, M.J. Prostaglandin synthesis in isolated rat kidney glomeruli. Proc. Nat1. Acad. Sci. USA 76:1155, 1979.

13) Sraer, J., Foidart, J., Chansel, D., Mahieu, P., Kouznetzova, B., and Ardaillou, R. Prostaglandin synthesis by mesangial and epithelial glomerular cultured cells. FEBS Lett. 104:420, 1979.

14) Kreisberg, J.I., Karnovsky, M.J., and Levine, L. Prostaqlandin production by homogeneous cultures of rat glomerular epithelial and mesangial cells. Kidney Int. 22:355, 1982.

15) Walker, B.R. Diuretic response to acute hypoxia in the conscious dog. Am. J. Physiol. 243:F440, 1982. 


\section{PROSTAGLANDINS}

16) Burdowski, A.J., Brookins, J., Kadowitz, P.J., Jubiz, W., Salmon, J., Moncada, S., and Fisher, J.W.

Relationships between prostanoids and renin on erythropoietin (Ep) production following hypoxic stimulation.

Exp. Hemato1. 8, Suppl. 8:310(A), 1980.

17) Wennmalm, A. Prostacyclin-dependent coronary vasodilation in rabbit and guinea-pig hearts.

Acta Physi 1. Scand. 106:47, 1979.

18) Kirstein, A. Cardiac prostacyclin release: Stimulation by hypoxia and various agents. Scand. J. Haematol. S34:105, 1979.

19) Markelonis, G. and Garbus, J. Alterations of intracellular oxidative metabolism as stimuli evoking prostaglandin biosynthesis. Prostaglandins 10: 1087, 1975.

20) Lands, W.E.M., Sauter, J., and Stone, G.W. Oxygen requirement for prostaglandin biosynthesis. Prostaglandins Med. 1:117, 1978.

21) Hagiwara, M., McNamara, D.B., Chen, I-Li, and Fisher, J.W. Role of endogenous prostaglandin $E_{2}$ in erythropoietin production and dome formation by human renal carcinoma cells in culture. J. Clin. Invest. 74:1252, 1984.

22) Erman, A., and Raz, A. Effects of bivalent cations on prostaglandin bjosynthesis and phospholipase $A_{2}$ activation in rabbit kidney medulla slices.

Biochem. J. 182:821, 1979.

23) Hagiwara, M., Chen, I-Li, and Fisher, J.W. Erythropoietin production in long-term cultures of human renal carcinoma cells. Exp. Cell Res. 154:619, 1984.

24) Ager, A., Gordon, J.L., Moncada, S., Pearson, J.D., Salmon, J.A., and Trevethick, M.A. Effects of isolation and culture on prostaglandin synthesis by porcine aortic endothelial and smooth muscle cells.

J. Cell. Physiol. 110:9, 1982.

Editor: A. Nies Received: 11-20-84 Accepted: 4-29-85 